\title{
Group size and habitat use by Black-necked Storks Ephippiorhynchus asiaticus in an agriculture-dominated landscape in Uttar Pradesh, India
}

\author{
K. S. GOPI SUNDAR
}

\section{Summary}

Group size and habitat use of Black-necked Storks Ephippiorhynchus asiaticus were studied over a 30-month period in an unprotected landscape with a mosaic of natural and manmade features in Etawah and Mainpuri districts, Uttar Pradesh, India. Group size was largely one or two and never more than a family of two adults and three young. Group size did not change with season or across habitat types. Black-necked Storks used habitats to different extents across years and seasons. Wetlands were preferred in all seasons and rice-paddies were preferred during the monsoon. The use of irrigation canals was consistent across seasons and was always in proportion to their availability. Irrigation canals and crop-fields, particularly flooded rice-fields, provided some additional habitat to Black-necked Storks, but catered to the population for a very small period of time. While some studies have demonstrated that flooded rice-fields are useful for wintering waterbird species, conversion of natural wetlands to crop-fields will not be advantageous to Black-necked Storks, and these habitats need to be preserved to conserve the species.

\section{Introduction}

The intensification of agriculture the world over has led to the decline in the extent of wetlands, in turn endangering the flora and fauna dependent on these habitats (Green 1989, McLaughlin and Mineau 1995). In India, agricultural intensification following the implementation of the Green Revolution in the mid-196os resulted in an enormous increase in the area of crop-fields which, in turn, have caused severe declines in the extent of a variety of natural habitats including wetlands and associated wildlife (Scott 1989, Foote et al. 1996, Ramankutty and Foley 1999). Black-necked Stork Ephippiorhynchus asiaticus is a wetland species found in South Asia (E. a. asiaticus, population estimate absent but thought to be <1,000; Wetlands International 2002) and Australia (E. a. australis, estimated population c. 30,000; Wetlands International 2002). Though thought to be stable globally, in India the species is thought to be declining as a result of habitat loss and deterioration principally due to increased agriculture, and there has been a move to afford greater protection to the species by moving it up from Schedule IV of the Indian Wildlife (Protection) Act to Schedule I (Rahmani 1989, Elliott 1992, Dorfman et al. 2001, Wetlands International 2002, A. R. Rahmani verbally, 2002). Previous reviews on the species have lamented the lack of even basic 
ecological information on the species (Rahmani 1989, Elliott 1992). In South Asia, ecological studies have so far been conducted largely in protected wetland areas and have focused on its behaviour (Kahl 1973, Ishtiaq 1998, Maheswaran 1998), foraging ecology (Maheswaran and Rahmani 2001, 2002) and breeding biology (Kahl 1970, Sundar 2003). Most observations of Black-necked Storks in India are from protected areas with vast tracts of managed or natural wetlands, and the habits of the species outside such areas with more varied habitats and increased human disturbance are only just being documented. Recent information shows that most of the population and breeding activity of Black-necked Storks is outside protected areas (Sundar 2003), in stark contrast to the previous belief that most of the population in India is confined to protected areas (Elliott 1992, Benn et al. 1995). Information on the habits of the species in these areas is urgently required to determine its requirements and plan appropriate conservation measures.

Black-necked Storks are known to utilize a wide variety of wetland habitats, both freshwater and saline (Ali and Ripley 1989), but are thought to prefer extensive, undisturbed, freshwater natural wetlands for foraging (Luthin 1987, Elliott 1992). They are described as non-social, found largely as single birds, pairs or small family parties, and shy of human activity (Luthin 1987, Ali and Ripley 1989, Elliott 1992). In Irian Jaya (W. New Guinea), many birds are known to congregate in response to reduction of wetland area during the dry season (Elliott 1992). However, information on habitat use is anecdotal, and there is no information on responses to changes in climate and land use. The majority of the Blacknecked Storks in India are found in the Indo-Gangetic flood plains, particularly in Uttar Pradesh (Rahmani 1989, Sundar and Kaur 2001). Here, the seasons are distinct and the area experiences acute increase in the availability of water during the monsoon and corresponding shortage during the summer (Gopal and Sah 1993). In addition, these areas are presently experiencing major changes in land-use practices and intensification of agriculture (Ramankutty and Foley 1999) leading to loss of natural components of the landscape (Scott 1989, Sethi 2001, Sundar 2001). Recent studies on the utility of flooded rice-fields to waterbirds have demonstrated that these fields can form surrogates of natural wetlands, which they resemble functionally, and can be appropriate foraging habitats to many species (Fasola and Ruíz 1996, Elphick 2000). However, in a landscape with both natural and man-made wetlands, foraging habits of Blacknecked Stork are unknown. This information is crucial to determine whether rice-fields are suitable surrogates of natural wetlands for this species.

In this paper, I report the results of an investigation to answer the following questions:

1. What is the effect of season and habitat on group size of Black-necked Stork in a landscape with a mosaic of natural and man-made habitats?

2. What is the pattern of habitat use by Black-necked Storks in a landscape that has a mosaic of natural and man-made wetlands?

\section{Study area}

Fieldwork was carried out in Etawah and Mainpuri districts of Uttar Pradesh. Intensive observations were carried out in northern Etawah and southern 


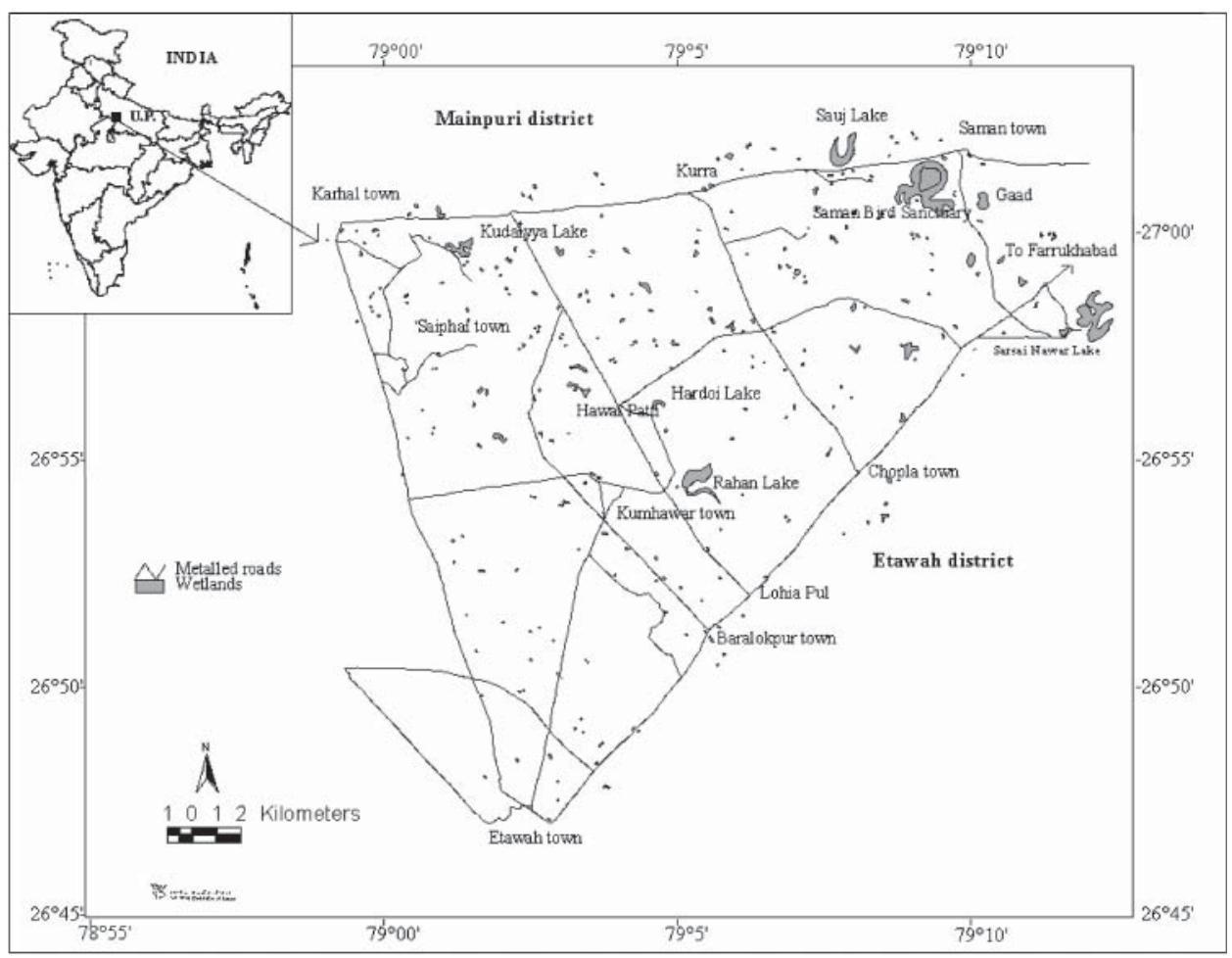

Figure 1. Intensive study area showing the principal roads used to study group size and habitat use of Black-necked Storks in Uttar Pradesh (U.P.). Locations of major towns are indicated.

Mainpuri in an area of nearly $50 \mathrm{~km}^{2}$ (Figure 1 ). This region comprises a part of the Gangetic flood plain, which is extremely flat and homogeneous (Scott 1989, Gopal and Sah 1993), and known to have many wetlands that are important for wintering waterbirds (Scott 1989). The two districts have a large population of Black-necked Storks (Rahmani 1989, Sundar 2003). In the study area, 29 territorial pairs were documented, with varying breeding success each year (see Sundar 2003).

The landscape is a mosaic of natural wetlands, crop-fields, irrigation canals, human habitation and associated structures, and trees thinly dispersed over the landscape. Agriculture is the main occupation of as many as $78 \%$ of the people of the state, and as many as $81 \%$ in Etawah and Mainpuri districts (Bhatt 1997, Anon 2001). The principal crops in the study area are rice Oryza sativa and wheat Triticum aestivum. Breaches in irrigation canals resulted in the formation of many wetlands that resemble natural wetlands formed by flooding of rainwater.

Three seasons can be differentiated based on temperature and rainfall regimes, namely summer (March to June), monsoon (July to October) and winter (November to February). Most of the precipitation occurs during the south-west monsoon with an annual average (1990-2001) of $882 \mathrm{~mm}$ rainfall, and temperature varies between $1{ }^{\circ} \mathrm{C}$ and $50^{\circ} \mathrm{C}$ (District Magistrate's Office, Etawah, verbally). 
During the study period, the monsoon occurred at the same time each year with an approximately equal intensity of rainfall (2000: 2,519 mm; 2001: 2,394 mm).

\section{Methods}

Group size and habitat use were assessed between December 1999 and June 2002. Black-necked Storks in the study area were well spread out and rare to sight. This made it difficult to obtain workable ecological data using systematic and conventional methods such as transects. Therefore, opportunistic records were maintained while driving along the network of c. $250 \mathrm{~km}$ of roads in the study area. All pairs and families present in the study area were documented in detail throughout the study (see Sundar 2003) to check whether opportunistic observations on group sizes were adequate to obtain information on this aspect. Roads were driven an average of three times a week. At each sighting of Black-necked Storks, the number of birds and broad habitat type were noted. The broad habitat types were:

1. Crop-fields: The principal crops were rice during the monsoon and wheat during the winter. Rice-fields were flooded nearly all the time, with few drained just prior to the harvest in October/November, and resembled natural wetlands more than wheat-fields did. Wheat-fields were flooded intermittently to moisten the soil, particularly immediately after the planting in the winter, but were without standing water at all times, and were dry prior to the harvest in March/April. Rice-fields frequently had wetland plants including Nelumbo spp., many species of grasses and rarely Cyperus and Elaeocharis spp. Many fields were left uncultivated after the wheat harvest, though a few farmers planted corn, barley, sugarcane, vegetables and fruit. Among cultivated fields, Black-necked Storks used only rice- or wheat-fields. The term "crop-fields" in this paper refers to only rice- and wheat-fields while describing habitat use by Black-necked Storks, but includes other fields in the measurement of habitat availability.

2. Fallow fields: These were crop-fields that were left uncultivated (dry/inundated) after the harvest of wheat in preparation for the monsoon before planting rice. Black-necked Storks mainly used inundated fallow fields.

3. Natural wetlands: These were areas that were inundated seasonally (rainfall) and/or perennially (rainfall and irrigation canals) and were characterized by shallow water seldom exceeding $1 \mathrm{~m}$, with the presence of vegetation including species of Typha, Elaeocharis, Nymphaea, Nelumbo, various grasses and other aquatic flora in varying combinations (see Scott 1989 for a fuller description). Ponds and lakes were often deeper immediately after the monsoon, but were shallow and resembled other wetlands most of the year and were included in this broad habitat type. These wetlands were utilized for grazing cattle, fishing, and a variety of plants were harvested for human and cattle use by villagers; none were left completely undisturbed. Seasonal areas were classified as "wetlands" when with water and classified as "other habitats" when they dried.

4. Canals: Irrigation canals formed a permanent feature of the landscape in the study area. These were permanent structures with varying water levels depending on the release or stopping of water at the source. Canals did not 
have any vegetation in the water, but short grass, Ipomoea carnea, Prosopis juliflora and a few other plant species grew on the sloping sides. Several canals had metalled roads running alongside them.

5. Other habitats: These included saline wastelands, degraded scrub-forests, grasslands, ravines, rivers and human habitation. For habitat use and preference analyses, Black-necked Storks seen flying, perched on trees, or standing on roads were included in this category.

All sightings for a season were pooled; only the winter season of 2002 was incomplete, in that data were not collected in November and December. Very few observations were obtained during the summer of 2001 and these data were not included in seasonal or inter-annual analysis of either group size or habitat preference. Group-size data were not normally distributed either seasonally or for the entire sample (One-sample Kolmogorov-Smirnov test, $P<0.0001$ ) and non-parametric tests (Univariate Kruskal-Wallis (K-W) test and Wilcoxon rank sign test) were used to determine the effect of year, season and habitat type on group size.

A crude measure of habitat availability was determined each month during January 2001 to February 2002 by undertaking a $105 \mathrm{~km}$ road transect following Allan (1995). Visibility along the transects averaged $430 \mathrm{~m}$ on either side of the road (range: $o$ to $>1,000 \mathrm{~m}$ ). At each kilometre, presence of habitat types visible on either side of the road was noted. At the end of each transect, frequencies of each habitat type were summed to be used in analyses.

Habitat use and preference were investigated, with each group of Blacknecked Storks treated as a single replicate to avoid the problem of non-independence of birds occurring as pairs and families (e.g. Allan 1995). When habitat use and preference were analysed using individuals, similar results were obtained. Differences in habitat use by groups across years and seasons were tested using Friedman's two-way ANOVA. Habitat availability information obtained during January, May and September 2001 was taken to represent availability in winter, summer and monsoon respectively for all three years. This was appropriate because of similar intensity and period of rainfall throughout the study period. Habitat preference was ascertained using the non-mapping technique described by Marcum and Loftsgaarden (1980). This was appropriate for this study for various reasons. Some habitat types (e.g. ephemeral pools, and other wetlands) were too small and numerous to be individually mapped, and the presence of habitats in the form of a mosaic made complete mapping impractical. In addition, the exact boundaries were difficult to determine. Finally, due to continual changes in the landscape due to agriculture and season, mapping would have had to be carried out for each month and this was logistically not possible. The road transect used to assess availability covered all habitats that were present in the region and the coverage is thought to be adequate to obtain a representative of habitat availability. The summed frequencies of each habitat type each season were compared with the number of groups of Black-necked Storks seen in the respective habitat type using chi-square tests to determine whether habitats were used in proportion to their availability in a particular season. Seasonal preference/avoidance of individual habitat types was determined by generating Bonferroni confidence intervals at $95 \%$ confidence levels (Marcum and Loftsgaarden 1980). 


\section{Results}

\section{Group size}

A total of 503 sightings of Black-necked Stork groups were documented during the 27 months of the study. Overall mean group size $( \pm S E)$ was $1.42 \pm 0.03$. Most sightings were of single birds $(67 \%)$ and pairs $(26.8 \%)$, and the rest were families (Table 1). Among families, adults with one young were commoner $(50 \%$ of all sightings) than families with two $(34.6 \%)$ or three (15.4\%) young. In 2002 there were no families with three young and the maximum group size was four. Group size differed significantly between years (K-W test, $\chi^{2}=8.78$, d.f. $=2$, $P=0.012$; see Table 1). Group sizes of Black-necked Storks were similar across seasons and habitats (Table 2). Mean group sizes obtained each year by opportunistic sightings were not significantly different from mean group sizes calculated each year with data of known number of pairs and different sized families $\left(\chi^{2}=0.007\right.$, d.f. $\left.=2, P>0.1\right)$.

\section{Habitat use and preference}

Black-necked Storks used natural wetlands and crop-fields mostly (37\% and $28 \%$ of the total respectively, Figure 2). Most sightings of storks were in wetlands ( $n=189$ groups); most of the wetland use was during summer and winter $(n=189,39.7 \%$ each). Of sightings of groups in crop-fields $(n=141)$, most were seen in rice-fields during the monsoon (62.4\%), and fewer in wet winter-wheatfields $(22 \%)$ and dry summer-wheat-fields (15.6\%). Of all the sightings of storks in fallow fields $(n=52)$, most were in winter $(50 \%)$ and summer $(40.4 \%)$. The remainder of sightings $(n=121)$ were during flight, on trees or on the road.

Table 1. Frequency of sightings of different-sized groups and group size of Black-necked Storks in Etawah and Mainpuri, Uttar Pradesh, India.

\begin{tabular}{llccc}
\hline & & 2000 & 2001 & 2002 \\
\hline Size of group & One (\%) & 61.45 & 74.32 & 69.37 \\
& Two (\%) & 30.73 & 21.58 & 25.23 \\
& Families (3-5) (\%) & 7.82 & 4.1 & 5.4 \\
Mean group size \pm SE & & $1.54 \pm 0.06$ & $1.34 \pm 0.05$ & $1.37 \pm 0.06$ \\
No. of groups & & 186 & 206 & 111 \\
\hline
\end{tabular}

Table 2. Effect of season and habitat on group size of Black-necked Storks in different years in Etawah and Mainpuri districts, Uttar Pradesh, India.

\begin{tabular}{lllll}
\hline Year & Parameter & Test values & d.f. & $P$ \\
\hline 2000 & Season & $0.011^{a}$ & 2 & 0.995 \\
& Habitat & $2.935^{a}$ & 4 & 0.569 \\
2001 & Season & $6.012^{b}$ & 1 & $>0.1$ \\
& Habitat & $6.793^{a}$ & 4 & 0.147 \\
& Season & $6.943^{b}$ & 1 & $>0.1$ \\
& Habitat & $3.299^{a}$ & 4 & 0.509 \\
\hline
\end{tabular}

${ }^{a}$ Kruskal-Wallis test $\chi^{2}$ value; ${ }^{b}$ Wilcoxon rank sum test value. 


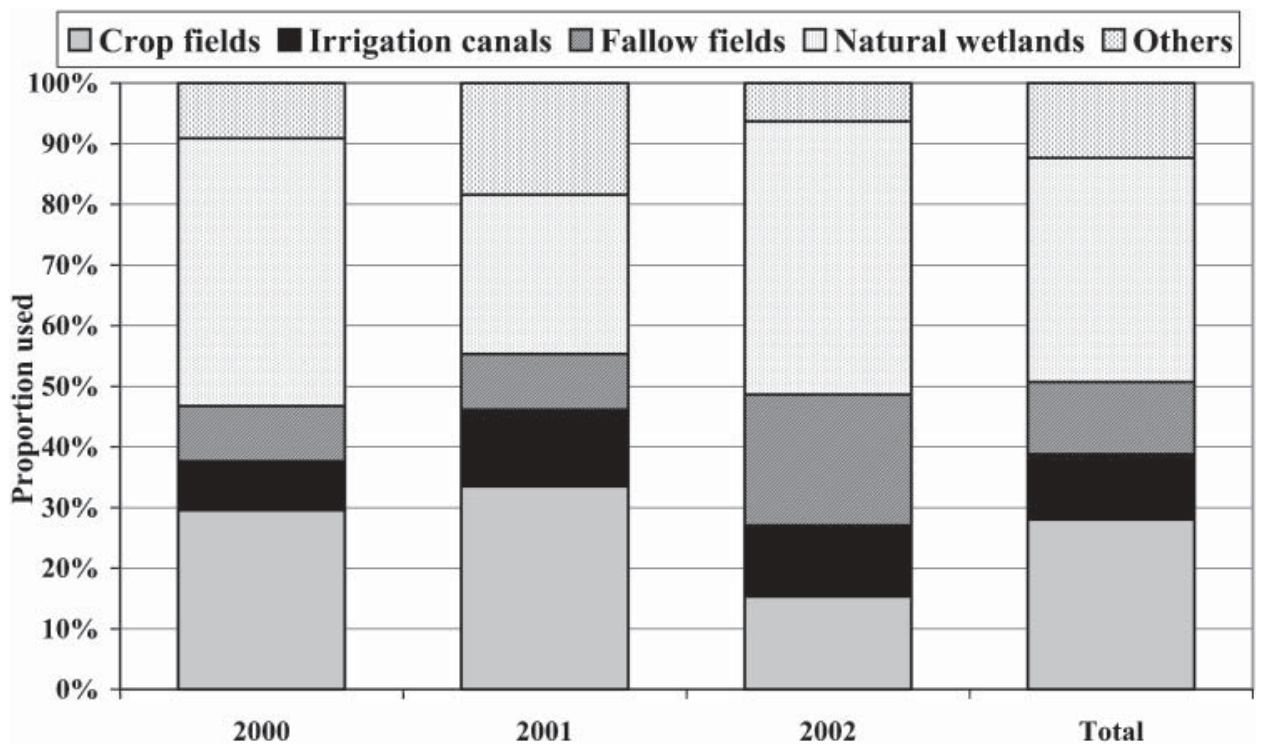

Figure 2. Annual variation in habitat use by Black-necked Storks in Etawah and Mainpuri districts, Uttar Pradesh, India.

The number of stork groups seen in different habitat types differed significantly between years (Friedman's two-way ANOVA, $\chi^{2}=7.8$, d.f. $=2, P<0.05$, Figure 2), warranting separate seasonal analyses for each year. The use of different habitats by storks differed significantly across seasons each year (Friedman's two-way ANOVA, $\chi^{2}=50.17$, d.f. $=6, P<0.0001$ ).

Each season, $\chi^{2}$ tests showed significant differences in the availability and use of habitat types by stork groups $(P<0.001)$. Bonferroni confidence intervals generated indicated that crop-fields were used significantly more than their availability during the monsoon each year, but were otherwise used far less in proportion to their availability (Table 3 ). Irrigation canals were used in equal

Table 3. Habitat preference by Black-necked Storks groups in Etawah and Mainpuri districts, Uttar Pradesh, India.

\begin{tabular}{|c|c|c|c|c|c|}
\hline \multirow[t]{2}{*}{ Year } & \multirow[t]{2}{*}{ Season } & \multicolumn{4}{|l|}{ Habitat type } \\
\hline & & Crop-fields & Irrigation canals & Fallow fields & Natural wetlands \\
\hline \multirow[t]{3}{*}{2000} & Winter & - & UA & + & + \\
\hline & Summer & UA & UA & + & + \\
\hline & Monsoon & + & UA & UA & + \\
\hline \multirow[t]{2}{*}{2001} & Winter & - & UA & - & + \\
\hline & Monsoon & + & UA & UA & UA \\
\hline \multirow[t]{2}{*}{2002} & Winter & - & UA & UA & + \\
\hline & Summer & UA & UA & + & + \\
\hline
\end{tabular}

Habitat preference inferred from 95\% Bonferroni's confidence intervals. +, used more than available; -, used less than available; UA, used in proportion to availability. Analysing preference for miscellaneous habitats was not applicable. 
proportion to their availability in all seasons. Fallow fields were either used in proportion to or more than their availability, being avoided only in the winter of 2001. Natural wetlands were almost always used more than their availability (Table 3).

\section{Discussion}

\section{Group size}

Black-necked Storks were seen only as single birds, pairs or family groups consisting of two adults with one, two or three young. The number of pairs successfully fledging young differed between years as did the number of young per successful pair (Sundar 2003), giving rise to annual differences in group size. Information on mean group size from opportunistic observations can, therefore, be used to provide an indication of breeding success in an area or in any given year.

Anecdotal information suggests that lack of flocking is characteristic for the species, though a few reports suggest that dry conditions do prompt flocking (Elliott 1992, Sundar 1999). In the study area, the extent of natural wetlands and flooded crop-fields decreased dramatically during the summer, but did not seem to be sufficiently low to prompt flocking. Black-necked Storks are large birds, entirely carnivorous (Ali and Ripley 1989, Ishtiaq 1998, Maheswaran and Rahmani 2001, pers. obs.) and require nearly $1 \mathrm{~kg}$ of live prey each day (Maheswaran and Rahmani 2002). The lack of flocking even during dry months may be because territories of individual pairs and families of storks are large and not limited by food availability. The irrigation canals crisscrossing the entire study area may have had a major role in preventing the need for flocking in this area by ensuring maintenance of wetlands, and sufficient food within. Flocking may have been absent also due to high competition for territories; pairs leaving their territories risk being usurped by other pairs. Territoriality and aggression levels of the species are known to increase with declining food availability (Maheswaran and Rahmani 2001), and may have been a factor in the lack of flocking. Many observations were made of families splitting up to feed in different areas, presumably within their territories. Whether this was a result of resources becoming patchy within territories or due to territorial behaviour was not clear. Studies to establish the factors determining territory size, choice of an area for a territory and distribution of resources within the territory over a year will be important to understand requirements of the species in the agricultural landscape.

\section{Habitat use and preference}

Variations in cropping pattern in different seasons caused storks to actively shift usage of different habitat types. Overall, however, natural wetlands and ricepaddies, which resembled natural wetlands, were clearly the most preferred habitats for Black-necked Storks. During the monsoon, many natural wetlands were too deep to be suitable as foraging grounds, and may have facilitated the observed shift to flooded crop-fields. Though detailed behavioural information 
was not collected during the study, casual observations suggested that the principal use of crop-fields for foraging was only during the monsoon, and in other seasons storks used them for resting and preening. In the summer, the extent of natural wetlands was much reduced. Flooding of fallow fields during this time before planting rice may have facilitated availability of some prey, and may explain the choice of this habitat during the summer along with natural wetlands. Casual observations suggested that storks were able to find prey, presumably insects, in these fields. Irrigation canals were the only consistent habitat, and storks should have used them more in summers when water availability was generally low and canals also had shallow water. That they did not implies that forage quality in canals was lower than in other habitat types.

\section{Implications for management}

This study was carried out in an area that has the highest known population of Black-necked Storks with the highest known number of breeding pairs (Sundar 2003), and the results probably mirror a situation that is most appropriate for Black-necked Storks outside of protected areas with vast tracts of natural wetlands. The reasons for the lack of differences in group size with respect to season and habitat are not entirely apparent from this study, and need detailed investigation with respect to territory size, availability of forage within them and related aspects. The extent of the use of crop-fields by Black-necked Storks was previously unknown, as was the consistent use of irrigation canals for foraging. It has always been believed that Black-necked Storks need comparatively undisturbed, wide tracts of freshwater (and infrequently saline) wetlands to forage (Luthin 1987, Elliott 1992). In Etawah and Mainpuri, however, nearly 30\% of all sightings of these birds were in crop-fields, principally flooded rice-paddies. Elliott (1992), commenting on the response of the species to changes in land use in recent years, opines that it may have benefited from provision of such "artificial wetlands" in many areas. In the Gangetic floodplain, however, if crop-fields were to replace perennial, natural wetlands, Black-necked Storks would be without a preferred foraging habitat for most of the year. The Gangetic floodplain, found largely in Uttar Pradesh, holds among the most extensive freshwater wetlands left in India (Scott 1989), with wetlands in most other states being heavily disturbed by human activity or completely drained for agricultural activity (Foote et al. 1996). This is perhaps why most of the population of Black-necked Storks recorded in India is in this state (Rahmani 1989, Sundar and Kaur 2001). Information on habitat use and preference of Black-necked Storks from Etawah and Mainpuri indicate that these birds would not fare well in states with a reduced extent of natural wetlands and/or land use with dry crops. Luthin's (1987) belief that the population of Black-necked Storks in most of Asia is fragmented is very likely true, though for a few months flooded rice-fields may provide a contiguous habitat. Rice-paddies may thus be preventing functional fragmentation of subpopulations of storks by forming contiguous wetland-like habitats and assisting in the dispersal of young birds. This idea needs to be explored through a combination of genetic and telemetry studies and has enormous implications for maintenance and management of Black-necked Stork populations in heavily cultivated areas, and for planning land use in landscapes that continue to have breeding Black-necked Storks. 
The potential of crop-fields as habitats for a variety of waterbirds has elicited a great deal of interest in recent years (Fasola and Ruíz 1996, Elphick and Oring 1998, Elphick 2000). Many of these studies have suggested that crop-fields serve as surrogate habitat for several waterbird species. For Black-necked Storks it appears that rice-fields are important only during the monsoon. At other times, natural habitats are essential, suggesting that conversion of natural wetlands to crop-fields is not to be encouraged. Black-necked Storks are perennially territorial in the study area (pers. obs.) and very clearly prefer natural wetlands throughout the year. Natural wetlands never occupied more than $15 \%$ of the landscape, while the extent of crop-fields and associated habitat types frequently exceeded $50 \%$ of the habitat available. Crop-fields undergo sudden changes that are clearly not appropriate for Black-necked Storks. Fields are drained prior to harvesting and at this time do not provide any food for the storks, which feed mainly on snakes, fish, small turtles and small waterbirds (Ali and Ripley 1980, Elliott 1992, G. Maheswaran verbally, pers. obs.). Finally, after the harvest of wheat in February or May, crop-fields are left dry and uncultivated until the onset of the monsoon in June/July, reducing the extent of required habitats for storks in the landscape. Recent attempts to increase agricultural land in the region with no regard for conserving natural habitats (Sethi 2001, Sundar 2001) will, therefore, have deleterious effects on fauna such as Black-necked Stork. Farming practices and development projects in this region that attempt to work at a landscape level need to be regulated to incorporate maintenance and preservation of natural wetlands and reduce changes in land-use patterns, particularly if the change is to drier crops.

The lack of information on specific factors affecting population declines in farmland birds has been a concern the world over (e.g. Siriwardena and Schifferli 1998). For Black-necked Storks, this study provides evidence that deterioration of foraging habitat was probably responsible for the decline purported for the species in India. Of all the states from which this species is known in India, Uttar Pradesh seems to be the only one with conditions and land use suitable for Black-necked Storks. Gujarat and Rajasthan, other states with Black-necked Storks, are semi-arid with few perennial wetlands. In Madhya Pradesh, soybean is grown in $90 \%$ of the cultivated area, and these fields are inhospitable to waterbirds since they are relatively dry and are heavily managed with intensive application of pesticides and constant watering using sprinklers. Uttar Pradesh, therefore, provides the best hope for the survival of this species in India and it is necessary to preserve the landscape in the state in order to maintain suitable conditions for large waterbirds. The state also has good numbers of other large waterbirds such as Sarus Cranes Grus antigone, Painted Storks Mycteria leucocephala, Open-billed Storks Anastomus oscitans, White-necked Storks Ciconia episcopus and three species of ibis, which are also dependent on wetlands for their survival. It would be difficult for populations of large, territorial, carnivorous, slow-breeding species such as Black-necked Stork to recover once reduced, and it is crucial that preferred habitats of the species are preserved. Lack of ecological information on the requirements of the species outside protected areas is a key deterrent to understanding what conservation practices are required in these areas to better aid the species' survival. This needs to be urgently rectified, given the rapid conversion that the Indian landscape is experiencing. 


\section{Acknowledgements}

Observations made during this study were carried out while undertaking field work in the project "Impact of Land Use Change on the Habitat and Ecology of the Indian Sarus Crane (Grus a. antigone) in the Indo-Gangetic Flood Plains" of the Wildlife Institute of India (WII) and I am grateful to the Director and B. C. Choudhury for infrastructure and facilities. The International Crane Foundation (ICF) and the U.S. Fish \& Wildlife Services provided funding and facilities during the writing of the paper and I thank G. Archibald, D. Ferguson and J. Harris for facilitating the process. M. S. Rana (WII) and B. Didrickson (ICF) provided library support. I gratefully acknowledge C. S. Elphick, F. Ishtiaq, G. Maheswaran and A. R. Rahmani for providing literature. R. Chauhan and family are thanked for making the stay in Etawah during fieldwork comfortable. R. Chauhan, S. Chauhan, D. Singh and A. Verma assisted in fieldwork. The map was prepared by P. Lal (WII), and I am grateful for his assistance. S. Buckton, C. S. Elphick, A. Lacy, G. Maheswaran, A. R. Rahmani and K. Sivakumar provided comments that greatly improved a previous manuscript.

\section{References}

Ali, S. and Ripley, S. D. (1989) Pp. 93-103 in Handbook of the birds of India and Pakistan. Volume 1. Divers to Hawks. Bombay: Oxford University Press.

Allan, D. G. (1995) Habitat selection by the Blue cranes in the Western Cape Province and the Karoo. S. Afr. J. Wildl. Res. 25: 90-97.

Anon. (2001) India 2001. A reference manual. New Delhi: Publications Division, Ministry of Information and Broadcasting, Government of India.

Benn, G. A., Kemp, A. C. and Begg, K. S. (1995) The distribution, size and trends of the saddlebilled stork Ephippiorhynchus senegalensis in South Africa. S. Afr. J. Wildl. Res. 25: 98-105.

Bhatt, S. C. (ed.) (1997) Pp. 391-1035 in The encyclopaedic district gazetteers of India. Central Zone Volume 6: Uttar Pradesh. New Delhi: Government of India.

Dorfman, E. J., Lamont, A. and Dickman, C. R. (2001) Foraging behaviour and success of Black-necked Storks (Ephippiorhynchus asiaticus) in Australia: implications for management. Emu 101: 145-149.

Elliott, A. (1992) Family Ciconiidae (Storks). Pp. 441-442 in J. del Hoyo, A. Elliott and J. Sargatal, eds. Handbook of the birds of the world. Volume 1. Barcelona: Lynx Edicions.

Elphick, C. S. (2000) Functional equivalency between rice fields and seminatural wetland habitats. Conserv. Biol. 14: 181-191.

Elphick, C. S. and Oring, L. W. (1998) Winter management of Californian rice fields for waterbirds. J. Appl. Ecol. 35: 95-108.

Fasola, M. and Ruíz, X. (1996) The value of rice fields as substitutes for natural wetlands for waterbirds in the Mediterranean region. Col. Waterbirds 19: 122-128.

Foote, A. L., Pandey, S. and Krogman, N. T. (1996) Processes of wetland loss in India. Environ. Conserv. 23: 45-54.

Gopal, B. and Sah, M. (1993) Conservation and management in India: Case-study of the river Yamuna. Environ. Conserv. 20: 243-254.

Green, B. H. (1989) Agriculture impacts on the rural environment. J. Appl. Ecol. 26: 793-802.

Ishtiaq, F. (1998) Comparative ecology and behaviour of Storks in Keoladeo National Park, Rajasthan, India. Unpublished Ph.D. thesis, Centre of Wildlife and Ornithology, Aligarh Muslim University, Aligarh. 
Kahl, M. P. (1970) Observations on the breeding of storks in India and Ceylon. J. Bombay Nat. Hist. Soc. 67: 453-461.

Kahl, M. P. (1973) Comparative ethology of the Ciconiidae. Part 6. The Black-necked, Saddlebill, and Jabiru Storks (Genera Xenorhynchus, Ephippiorhynchus and Jabiru). Condor 75: $17-27$.

Luthin, C. S. (1987) Status of and conservation priorities for the world's stork species. Col. Waterbirds 10: 181-202.

McLaughlin, A. and Mineau, P. (1995) The impact of agricultural practices on biodiversity. Agric. Ecosyst. Environ. 55: 201-212.

Maheswaran, G. (1998) Ecology and behaviour of Black-necked Stork (Ephippiorhynchus asiaticus Latham, 1790) in Dudwa National Park, Uttar Pradesh. Unpublished Ph D. thesis, Centre of Wildlife and Ornithology, Aligarh Muslim University, Aligarh.

Maheswaran, G. and Rahmani, A. R. (2001) Effects of water level changes and wading bird abundance on the foraging behaviour of Black-necked storks Ephippiorhynchus asiaticus in Dudwa National Park, India. J. Biosci. 26: 373-382.

Maheswaran, G. and Rahmani, A. R. (2002) Foraging behaviour and feeding success of the Black-necked Stork (Ephippiorhynchus asiaticus) in Dudwa National Park, Uttar Pradesh, India. J. Zool. (Lond.) 258: 189-195.

Marcum, C. L. and Loftsgaarden, D. O. (1980) A nonmapping technique for studying habitat preferences. J. Wildl. Mgmt. 44: 963-968.

Rahmani, A. R. (1989) Status of the Black-necked Stork Ephippiorhynchus asiaticus in the Indian subcontinent. Forktail 5: 99-110.

Ramankutty, N. and Foley, J. A. (1999) Estimating historical changes in global land cover: Croplands from 1700 to 1992. Global Biogeochem. Cycles 13: 997-1027.

Scott, D. A. (ed.) (1989) Pp. 402-403 in A directory of Asian wetlands. Gland, Switzerland \& Cambridge, U.K.: IUCN.

Sethi, N. (2001) Last call. Down to Earth 10(5): 25-29.

Siriwardena, G. M. and Schifferli, L. (1998) Birds and agricultural change: past, present and future research for conservation and management. Proc. 22nd Int. Ornithol. Congr., Durban. Ostrich 69: 165.

Sundar, K. S. G. (1999) Black-necked storks, Sarus Cranes and Drongo-cuckoos. Newsletter for Birdwatchers 39(5; Sept/Oct): 71-72.

Sundar, K. S. G. (2001) Where the Sarus duet. Sanctuary Asia xxi(5): 62-67.

Sundar, K. S. G. (2003) Notes on breeding biology of Black-necked Storks Ephippiorhynchus asiaticus in Etawah and Mainpuri districts, Uttar Pradesh, India. Forktail 19: 15-20.

Sundar, K. S. G. and Kaur, J. (2001) Distribution and nesting sites of the Black-necked Stork Ephippiorhynchus asiaticus. J. Bombay Nat. Hist. Soc. 98: 276-278.

Wetlands International (2002). P. 57 in Waterbirds population estimate. Third Edition. Wageningen, The Netherlands: Wetlands International (Wetlands International Global Series No. 12).

\section{K. S. GOPI SUNDAR}

Principal Co-ordinator, Indian Cranes and Wetlands Working Group, International Crane Foundation, E-11376, Shady Lane Road, Baraboo, WI 53913-0447, USA (e-mail: gopi@savingcranes.org)

Current address: C/o Wildlife Protection Society of India, M-52, Greater Kailash Part-I, New Delhi - 110048, India 